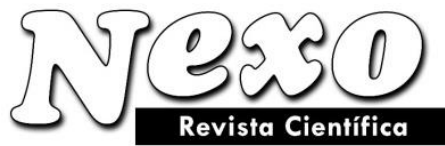

\title{
The effect of drought stress and nitrogen fertilization on the active ingredient, chlorophyll $A$ and $B$, and chlorophyll index of henna
}

\section{El efecto del estrés por sequía y la fertilización con nitrógeno sobre el ingrediente activo, clorofila $\mathrm{A}$ y $\mathbf{B}$, y el índice de clorofila de la henna}

\author{
Hassan Sarhadi ${ }^{1}$, Jahanfar Daneshian ${ }^{2 *}$, Seyyed Alireza Valadabadi ${ }^{1}$, Hossein Heidary \\ Sharafabad $^{3}$, Gholamreza Afsharmanesh ${ }^{4}$
}

${ }^{1}$ Department of Agronomy, Takestan Branch, Islamic Azad University, Takestan, Iran.

${ }^{2}$ Professor, Seed and Plant Improment Institute Agriculture Research, Education and Extension Organization, Tehran, Iran.

${ }^{3}$ Department of Agronomy, Science and Research Branch, Islamic Azad University, Tehran, Iran.

${ }^{4}$ Associate Professor, Agriculture and Natural Resources Research and Education Center, Kerman, Iran.

Corresponding author email: J.daneshian@areeo.ac.ir

(Recibido/received: 16-July-2020; aceptado/accepted: 19-September-2020)

\begin{abstract}
The response of active ingredient, chlorophyll $a$ and $b$ contents, and chlorophyll index of henna to different rates of $\mathrm{N}$ fertilization and drought stress was explored in a split-split-plot experiment based on a randomized complete block design with four replications in the research farm of Jiroft Branch, Islamic Azad University, Jiroft, Iran in the 2016-2017 growing season. In the current study, the main plot was assigned to drought stress at three levels (including irrigation to supply $100 \%, 75 \%$ or $50 \%$ of plant water requirement), the sub-plot was assigned to $\mathrm{N}$ fertilization at three rates $\left(50,100\right.$ or $150 \mathrm{~kg} \mathrm{ha}^{-1}$ pure $\left.\mathrm{N}\right)$, and the sub-sub-plot was assigned to ecotype at three levels (Bami, Bushehri, and Rudbari). The results showed that the effect of drought level was significant on active ingredient and chlorophyll index at the $p<0.01$ level and on chlorophyll $a$, total chlorophyll, and chlorophyll $a / b$ ratio at the $p<0.05$ level. But, it could not influence chlorophyll $b$ significantly. The effect of $\mathrm{N}$ fertilization was significant on most studied traits at the $p<0.01$ level, but its effect was significant on the chlorophyll index at the $p<0.05$ level and insignificant on dye and chlorophyll $b$. According to the results, it seems that the application of $100 \mathrm{~kg} \mathrm{ha}^{-1} \mathrm{~N}$ and the irrigation to supply $75 \%$ of plant water requirement can contribute to having more fresh plants with the higher active ingredient and dye contents.
\end{abstract}

Keywords: Henna, Drought stress, Nitrogen, Active ingredient, Chlorophyll, Chlorophyll index 


\section{RESUMEN}

La respuesta del ingrediente activo, el contenido de clorofila ayb, y el índice de clorofila de la henna a diferentes tasas de fertilización $\mathrm{N}$ y estrés por sequía se exploró en un experimento de parcela dividida dividida basado en un diseño de bloques completos al azar con cuatro repeticiones en la granja de investigación. de Jiroft Branch, Islamic Azad University, Jiroft, Irán en la temporada de cultivo 2016-2017. En el estudio actual, la parcela principal se asignó al estrés por sequía en tres niveles (incluido el riego para suministrar el 100\%, 75\% o 50\% del requerimiento de agua de la planta), la subparcela se asignó a la fertilización con $\mathrm{N}$ en tres dosis (50, 100 o 150 kg ha-1 de N puro), y la sub-subparcela se asignó al ecotipo en tres niveles (Bami, Bushehri y Rudbari). Los resultados mostraron que el efecto del nivel de sequía fue significativo sobre el ingrediente activo y el índice de clorofila al nivel de $\mathrm{p}<0.01$ y sobre la clorofila a, clorofila total y la proporción de clorofila a / b al nivel de $\mathrm{p}<0.05$. Pero no pudo influir significativamente en la clorofila $\mathrm{b}$. El efecto de la fertilización con $\mathrm{N}$ fue significativo en la mayoría de los rasgos estudiados en el nivel $p<0.01$, pero su efecto fue significativo en el índice de clorofila en el nivel $\mathrm{p}<0.05$ e insignificante en el tinte y la clorofila $b$. Según los resultados, parece que la aplicación de $100 \mathrm{~kg}$ ha-1 $\mathrm{N}$ y el riego para suplir el $75 \%$ del requerimiento de agua de la planta pueden contribuir a tener más plantas frescas con mayor contenido de ingrediente activo y colorante.

Palabras clave: Henna, Estrés por sequía, Nitrógeno, Principio activo, Clorofila, Índice de clorofila

\section{INTRODUCTION}

The global approach to the use of medicinal and industrial plants and natural compounds in medicinal, cosmetic, and food industries and the resulting attention of people, authorities, and industries to the use of medicinal and aromatic herbs have created a paramount need for extensive basic and applied research on these herbs. The diversity of species and genetic reserves is the distinguishing characteristic of the plant species around the world, and by producing medicinal plant species that are of high medicinal and industrial value (Ibrahimi, 2001), we can not only satisfy the domestic markets but also make way into the global markets without a competitor.

Even though the science of medicine has always been characterized by medicinal herbs and the supply of herb-based medications, attempts to restore this feature has been overlooked whilst the enhancement of the goals of medicine whose building blocks are the medicinal herbs is inevitable. A review of the activities pertaining to medicinal herbs, including research and economic activities, as well as the medicinal and cosmetic production with plant origins shows deficiencies, problems, and constraints concerning the work areas, collection and extraction of the plants from natural landscapes, input requirements, planting, cultivating and harvesting operations, post-harvest operations (processing), and marketing and trade of medicinal herbs and their product; it would be impossible to boom this potential production sector and to ensure its profitability for producers if these constraints and challenges are not tackled (Osareh M. \& Akhlaghi, 2009). Presently, attempts have been increasingly focused on updating our information about medicinal and industrial plant species (Orwa et al., 2009). Henna is an industrial and medicinal plant that is considered as a natural dye and has a plethora of applications in textile, carpet-weaving and cosmetics industries such as hair dye production, soap production and so on; 
it is also used in paper and tannery industries (Chaudhary et al., 2010). Also, the pharmacological properties of henna include its antifungal and antibacterial effects (Azadbakht, 1999).

Population growth and climate change have challenged agronomists and breeders of the $21 \mathrm{st}$ century to produce useful plants in water-deficient environments whereas 75 percent of total water of the world is consumed by agriculture (Molden, 2007). On the other hand, about 26 percent of the arable lands of the world are located in arid areas (REF). Among various factors, drought is the most important factor limiting crop production (REF). Drought stress is multidimensional stress and causes different physiological impacts on plants (Altinkut et al., 2001). The best way to modify yield and its sustainability under soil moisture deficit conditions is to use physiological methods as the fastest way of developing new drought-tolerant varieties (Siddique et al., 2000). When plants are exposed to drought stress, they exhibit physiological responses (Ludlow \& Muchow, 1990). The knowledge of the physiological relationship of the traits can help plant breeders to select for the traits in breeding programs (Pandya et al., 1996). According to REF, the formation and accumulation of active ingredients tend to increase in plants under more severe drought conditions. The reports on the effect of water stress on active ingredients of plant species are contradictory reported that water stress increased the active ingredients. The accumulation of glands generating active ingredient as influenced by the loss of leaf area under drought stress has been mentioned as a reason for more accumulation of active ingredients in basils and peppermints. Chlorophyll is the green pigment of the plants that helps the absorption of solar radiation and its conversion to energy. It is believed that chlorophyll is very beneficial to the human body. The consumption of chlorophyll-containing foodstuff cleans the blood flow, solves bad breath and smell, neutralizes carcinogens, and prevents the decade of the teeth (Roleda et al., 2010). The maintenance of chlorophyll concentration in stressful conditions contributes to its photosynthesis stability (Khadem et al., 2010). Chlorophyll content has a positive, significant relationship with photosynthesis rate, and accordingly, high-yielding plants can be gained by selecting plants for higher chlorophyll content (Pandey \& Singh, 2010). Water stress is a chlorophyll limiting factor.

Furthermore, $\mathrm{N}$ availability is an important factor that influences plant growth and development across the world (Rajala et al., 2009). The deficiency of water and $\mathrm{N}$ results in the loss of crop yields due to the loss of resources uptake and use efficiency. Besides, N supply affects leaf area index, leaf area duration, and chlorophyll content (Ding et al., 2005). It has been reported that high rates of nitrogen can improve photosynthesis rate and crop growth rate, and lower photosynthesis rate at lower $\mathrm{N}$ levels is related to lower chlorophyll content and lower activity of Rubisco (Fredeen et al., 1991). Research shows that $\mathrm{N}$ and drought stress influence leaf chlorophyll content significantly (Jones, 1980).

The secondary metabolites of the plants can be affected by environmental parameters and water deficiency which is the most important physiological and biochemical aspect of the plants (Petropoulos et al., 2008) and this can increase their active ingredient (Valadabadi et al., 2010) and (Vazque, 2010) and (Safaei et al., 2011) and (Taherkhani et al., 2011) and (Sarajuoghi et al., 2014). (Keshavarz et al., 2013) concluded that there was a positive, and significant correlation $\left(0.97^{* *}\right)$ between chlorophyll content and leaf N percentage. (Reynolds et al., 2007) also reported that leaf greenness duration as a sign of leaf chlorophyll was an indicator of leaf water state and deeper root system. Besides, this reflects a more rigorous photosynthesis system for the synthesis of assimilates and the extraction of water from the soil. (Sifola \& Barbieri, 2006) reported that drought stress accelerated leaf senescence by reducing leaf chlorophyll and dissolved proteins 
and that this reduction happened earlier in more sensitive genotypes. (Hajizadeh et al., 2011) reported a negative, significant correlation between chlorophyll $b$ and chlorophyll $a / b$ ratio and also a positive, significant correlation of chlorophyll $a$ and chlorophyll $b$ with total chlorophyll.

\section{MATERIALS AND METHODS}

To explore the response of active ingredient, chlorophyll $a$ and $b$ and chlorophyll index of henna ecotypes to different rates of $\mathrm{N}$ fertilizer and drought stress, a split-plot experiment was carried out in the research farm of Jiroft Branch, Islamic Azad University, Jiroft, Iran in the 2016-2017 growing season based on a randomized complete block design with four replications. Water deficit stress (at three rates of $100 \%, 75 \%$, and $50 \%$ of plant requirement), $\mathrm{N}$ fertilization (at three rates of 50,100 , and $150 \mathrm{~kg} \mathrm{ha}^{-1}$ pure $\mathrm{N}$ from urea source), and ecotype (at three levels of Bami, Bushehri, and Rudbari) were applied as the main plot, sub-plot, and sub-sub-plot, respectively. Before the experiment, two combined samples were taken from the depths of 0-30 and 30-60 $\mathrm{cm}$ of the soil profile (from four points selected on a zigzag path) and their $\mathrm{pH}, \mathrm{EC}$, total $\mathrm{N}$, absorbable $\mathrm{P}$ and $\mathrm{K}$, texture, and organic matter were measured. The results are presented in (Table 1).

Table 1: The results of soil analysis in the study site

\begin{tabular}{|c|c|c|c|c|c|c|c|}
\hline Depth & $\begin{array}{c}\text { Organic C } \\
(\%)\end{array}$ & $\begin{array}{c}\text { Total N } \\
(\%)\end{array}$ & $\begin{array}{c}\text { Absorbable P } \\
(\mathrm{ppm})\end{array}$ & $\begin{array}{c}\text { Absorbable K } \\
(\mathrm{ppm})\end{array}$ & $\begin{array}{c}\mathrm{EC} \\
(\mathrm{ds} / \mathrm{m})\end{array}$ & $\mathrm{pH}$ & Soil texture \\
\hline $0-30$ & 0.115 & 0.023 & 4.2 & 240 & 1.64 & 7.6 & Loam-sandy \\
\hline $30-60$ & 0.02 & 0.03 & 6.5 & 230 & 2.01 & 7.6 & Loam-sandy \\
\hline
\end{tabular}

Since henna seeds have a long dormancy period, they were exposed to $1000 \mathrm{ppm}$ gibberellic acid to induce the breaking of their dormancy. The seeds were sown in a nursery and as soon as the seedlings reached the height of about $15 \mathrm{~cm}$, they were transplanted in the main farm. Each plot was composed of 6 sowing rows with a length of $6 \mathrm{~m}$ and the inter-row spacing of $50 \mathrm{~cm}$. The main plots were spaced by $3 \mathrm{~m}$, the sub-plots were spaced by $1 \mathrm{~m}$, and the sub-sub-plots were spaced by $75 \mathrm{~cm}$. Also, a spacing of $2 \mathrm{~m}$ was left between the replications. The drought stress was applied using the evaporation pan. The water to be consumed was calculated for different levels of water deficit stress by the following equation based on the daily evaporation from evaporation pan:

$$
E T_{0}=K_{P} \times E_{p a n}
$$

in which $E T_{0}$ shows the reference plant evapotranspiration, $K_{P}$ represents evaporation from the pan, $E_{p a n}$ denotes the pan coefficients that was assumed to be 0.7 . Then, the water to be used was estimated by the following equation:

$$
E T_{C}=E T_{0} \times K_{C}
$$

in which $E T_{C}$ is the water consumed for the plant and $K_{C}$ is the crop factor that was assumed to be 1.1 as henna is a shrub. Then, different levels of water were calculated and they were applied using a volumetric contour as per the area of the plot. $\mathrm{N}$ fertilizer was applied at three stages (2 weeks before transplanting, about one month after the first stage, and before flowering). The 
studied ecotypes were prepared from the agricultural research centers of the counties of South Rudbar, Bushehr, and Bam. The recorded traits included leaf active ingredient, chlorophyll ( $a$ and $b$ ), chlorophyll $a / b$ ratio, and chlorophyll index measured on three randomly selected plants (after the elimination of the margins).

To find out the active ingredient content of henna leaves, $50 \mathrm{~mL}$ of $5 \%$ sodium bicarbonate was added to it and it was shaken with a circular shaker. This was repeated six times at 1-hour intervals for 15 minutes. Then, the samples were placed in a cold, dark place for 24 hours (the mouths of the Erlenmeyer were covered with a piece of aluminum foil). After 24 hours, $5 \mathrm{ml}$ of the extract (that was infiltrated with a centrifuge) was poured into a $50-\mathrm{mL}$ volumetric flask. The solution was adjusted to the desired volume by adding 5\% sodium bicarbonate, and its absorption was read at $490 \mathrm{~nm}$ with a spectrophotometer (the device was adjusted with 5\% sodium bicarbonate, so its zero was 5\%). To draw the calibration curve, $0.1 \mathrm{~g}$ of the active ingredient was weighed with a digital scale, was poured into a $100-\mathrm{mL}$ volumetric flask (ClassA), and was adjusted to the desired volume by adding 5\% sodium bicarbonate. Then, 1, 2, 3, 4, and $5 \mathrm{~mL}$ of the above standard was sampled and was added to a $1000-\mathrm{mL}$ volumetric flask (Class-A) and was adjusted by adding 5\% sodium bicarbonate. The absorption was read and active ingredient content was recorded in $\mathrm{mg} \mathrm{g}^{-1}$ leaf dry weight (LDW) according to the curve of active ingredient concentration in unknown samples.

The chlorophyll percentage (index) was measured with a manual chlorophyll-meter (SPAD, model CCM-200, the UK) in three parts of three similar fresh and healthy leaves from each plot whose average was recorded for the respective plot. Chlorophyll $a$ and $b$ were measured by the following procedure: $100 \mathrm{mg}$ of the fresh leaf (middle leaf used as chlorophyll sample without petiole) was placed in a tube and it was added with $10 \mathrm{~mL}$ of dimethyl sulfoxide (DMSO), and the samples were oven-dried at $65^{\circ} \mathrm{C}$ for 4 hours. Then, they were cooled down at room temperature, and the absorption of the extract was read at 645 and $663 \mathrm{~nm}$. The following equations were used to yield chlorophyll $a$ and $b$ contents in $\mathrm{mg} \mathrm{g}^{-1} \mathrm{FW}$ :

$$
\begin{aligned}
& \text { Chlorophyll } a=\left[\left(12.7 \times A_{663}\right)-\left(2.69 \times A_{645}\right)\right] V / 1000 \times W \\
& \text { Chlorophyll } b=\left[\left(22.9 \times A_{645}\right)-\left(4.68 \times A_{663}\right)\right] V / 1000 \times W
\end{aligned}
$$

in which $V$ is the volume of the solution, $A$ is the absorption read at 663 and $645 \mathrm{~nm}$, and $W$ is the fresh weight of the sample (in $\mathrm{g}$ ).

After it was ensured that data were normal, they were subjected to analysis of variance and means comparison in SAS v. 7 and MSTAT-C software packages.

\section{RESULTS AND DISCUSSION}

\subsection{Active ingredient content}

Active ingredient content was influenced by water deficit stress and ecotype significant at the $p<0.01$ and $p<0.05$ levels, respectively, but the effect of $\mathrm{N}$ rates and the interactions were not significant for this trait (Table 2).

Table 2: Analysis of variance for the studied traits 


\begin{tabular}{|c|c|c|c|c|c|c|c|}
\hline S.O.V. & df & $\begin{array}{c}\text { Active } \\
\text { ingredient }\end{array}$ & $\begin{array}{c}\text { Chlorophyll } \\
a\end{array}$ & $\begin{array}{c}\text { Chlorophyll } \\
b\end{array}$ & $\begin{array}{c}\text { Total } \\
\text { chlorophyll }\end{array}$ & $\begin{array}{c}\text { Chlorophyll } \\
a / b\end{array}$ & $\begin{array}{c}\text { Chlorophyll } \\
\text { index }\end{array}$ \\
\hline Replication & 3 & $1.99^{\text {ns }}$ & $0.05^{\text {ns }}$ & $0.003^{\text {ns }}$ & $0.06^{\text {ns }}$ & $1.33^{\text {ns }}$ & $35.30^{\text {ns }}$ \\
\hline $\begin{array}{c}\text { Low irrigation } \\
(A)\end{array}$ & 2 & $407.09^{* *}$ & $0.23^{*}$ & $0.003^{\text {ns }}$ & $0.27^{*}$ & $10.36^{*}$ & $19556.29^{* *}$ \\
\hline Error A & 6 & 3.25 & 0.03 & 0.005 & 0.04 & 1.70 & 47.41 \\
\hline $\begin{array}{c}\text { N fertilization } \\
(B)\end{array}$ & 2 & $0.44^{\text {ns }}$ & $0.41^{* *}$ & $0.008^{\text {ns }}$ & $0.49^{* *}$ & $14.73^{* *}$ & $52.21^{*}$ \\
\hline A $\times$ B & 4 & $1.28^{\text {ns }}$ & $0.03^{\text {ns }}$ & $0.01^{*}$ & $0.08^{*}$ & $2.24^{\text {ns }}$ & $393.47^{* *}$ \\
\hline Error B & 18 & 0.91 & 0.02 & 0.003 & 0.03 & 1.39 & 12.97 \\
\hline Ecotype $($ C $)$ & 2 & $4.31^{*}$ & $0.01^{\text {ns }}$ & $0.006^{\text {ns }}$ & $0.02^{\text {ns }}$ & $0.92^{\text {ns }}$ & $2.99^{\text {ns }}$ \\
\hline A $\times$ C & 4 & $2.72^{\text {ns }}$ & $0.01^{\text {ns }}$ & $0.008^{\text {ns }}$ & $0.02^{\text {ns }}$ & $0.98^{\text {ns }}$ & $191.26^{* *}$ \\
\hline B $\times$ C & 4 & $0.55^{\text {ns }}$ & $0.02^{\text {ns }}$ & $0.005^{\text {ns }}$ & $0.02^{\text {ns }}$ & $1.80^{\text {ns }}$ & $40.51^{\text {ns }}$ \\
\hline A $\times$ B $\times$ C & 8 & $1.37^{\text {ns }}$ & $0.02^{\text {ns }}$ & $0.02^{* *}$ & $0.03^{\text {ns }}$ & $4.05^{* *}$ & $115.91^{* *}$ \\
\hline Error C & 54 & 1.16 & 0.01 & 0.004 & 0.01 & 0.98 & 23.54 \\
\hline $\begin{array}{c}\text { Coefficient of } \\
\text { variation }(\%)\end{array}$ & 7.02 & 16.71 & 17.65 & 16.29 & 17.89 & 12.89 \\
\hline
\end{tabular}

ns, *, and ** show non-significance and significance at the $p<0.05$ and $p<0.01$ levels, respectively.

Means comparison (Table 3) showed that irrigation to supply $75 \%$ of plant water requirement (PWR) yielded the highest active ingredient content and the changes in irrigation interval and its application to supply $100 \%$ or $50 \%$ of PWR resulted in the loss of this trait. Among the ecotypes, Bami had the highest and Rudbari had the lowest active ingredient content. This trait was not significantly different among Bushehri, Bami, and Rudbari, the synthesis and accumulation of active ingredient tend to increase in plants suffering from drought stress. In total, reports are contradictory about the effect of water stress on the active ingredient content of different plant species. The accumulation of glands producing active ingredient under the loss of leaf area in drought stress can be mentioned as a reason for more accumulation of active ingredient in basils and peppermints. However, the results lead us to the conclusion that the variation of active ingredient content in drought stress depends on the plant species. So, it is inferred that genotype plays a key role in plant response to drought stress.

Table 3: Means comparison for the effect of low irrigation, $\mathrm{N}$ fertilization and ecotype on the studied traits

\begin{tabular}{|c|c|c|c|c|c|c|c|}
\hline & & $\begin{array}{c}\text { Active } \\
\text { ingredient }\end{array}$ & $\begin{array}{c}\text { Chlorophyll } \\
a\end{array}$ & $\begin{array}{c}\text { Chlorophyll } \\
b\end{array}$ & $\begin{array}{c}\text { Total } \\
\text { chlorophyll }\end{array}$ & $\begin{array}{c}\text { Chlorophyll } \\
a / b\end{array}$ & $\begin{array}{l}\text { Chlorophyll } \\
\text { index }\end{array}$ \\
\hline \multirow[t]{3}{*}{$\begin{array}{c}\text { Drought } \\
\text { stress }\end{array}$} & $\begin{array}{l}100 \% \text { of plant } \\
\text { water } \\
\text { requirement }\end{array}$ & $13.79 \mathrm{~b}$ & $0.62 \mathrm{a}$ & $0.18 \mathrm{a}$ & $0.80 \mathrm{a}$ & $3.45 \mathrm{ab}$ & $63.79 \mathrm{a}$ \\
\hline & $\begin{array}{c}75 \% \text { of plant } \\
\text { water } \\
\text { requirement }\end{array}$ & $19.24 \mathrm{a}$ & $0.59 \mathrm{a}$ & $0.17 \mathrm{a}$ & $0.76 \mathrm{a}$ & $4.13 \mathrm{a}$ & $30.01 \mathrm{~b}$ \\
\hline & $\begin{array}{l}50 \% \text { of plant } \\
\text { water } \\
\text { requirement }\end{array}$ & $13.10 \mathrm{~b}$ & $0.47 \mathrm{~b}$ & $0.16 \mathrm{a}$ & $0.63 \mathrm{~b}$ & $4.07 \mathrm{~b}$ & $19.09 \mathrm{c}$ \\
\hline \multirow[t]{3}{*}{$\mathrm{N}$ rate } & $50 \mathrm{~kg} \mathrm{ha}^{-1}$ & $15.25 \mathrm{a}$ & $0.44 \mathrm{~b}$ & $0.16 \mathrm{a}$ & $0.61 \mathrm{~b}$ & $2.84 \mathrm{~b}$ & $38.36 \mathrm{a}$ \\
\hline & $100 \mathrm{~kg} \mathrm{ha}^{-1}$ & $15.41 \mathrm{a}$ & $0.58 \mathrm{a}$ & $0.16 \mathrm{a}$ & $0.74 \mathrm{a}$ & $3.75 \mathrm{a}$ & $38.29 \mathrm{a}$ \\
\hline & $150 \mathrm{~kg} \mathrm{ha}^{-1}$ & $15.46 \mathrm{a}$ & $0.66 \mathrm{a}$ & $0.19 \mathrm{a}$ & $0.85 \mathrm{a}$ & $4.07 \mathrm{a}$ & $36.24 \mathrm{~b}$ \\
\hline \multirow[t]{3}{*}{ Ecotype } & Bami & $15.70 \mathrm{a}$ & $0.55 \mathrm{a}$ & $0.16 \mathrm{a}$ & $0.71 \mathrm{a}$ & $3.67 \mathrm{a}$ & $37.74 \mathrm{a}$ \\
\hline & Bushehri & $15.42 \mathrm{ab}$ & $0.57 \mathrm{a}$ & $0.18 \mathrm{a}$ & $0.76 \mathrm{a}$ & $3.62 \mathrm{a}$ & $37.84 \mathrm{a}$ \\
\hline & Rudbari & $15.01 \mathrm{~b}$ & $0.56 \mathrm{a}$ & $0.17 \mathrm{a}$ & $0.73 \mathrm{a}$ & $3.37 \mathrm{a}$ & $37.30 \mathrm{a}$ \\
\hline
\end{tabular}


Means with similar letter(s) in each column were not significantly different

\subsection{Chlorophyll a content}

Chlorophyll $a$ content was influenced by water deficit stress significantly $(p<0.05)$. Also, the effect of $\mathrm{N}$ fertilization was significant $(p<0.01)$ on this trait (Table 2). The application of water to supply $100 \%$ and $75 \%$ of PWR was related to the highest chlorophyll $a$ content and as water deficit stress was intensified to irrigation level to supply $50 \%$ of PWR, it was decreased from 0.62 and 0.59 to $0.47 \mathrm{mg} \mathrm{g}^{-1}$ significantly. Also, the results showed that $\mathrm{N}$ application at the rates of 100 and $150 \mathrm{~kg} \mathrm{ha}^{-1}$ improved chlorophyll $a$ content significantly. The lowest chlorophyll $a$ content was obtained from plants treated with $50 \mathrm{~kg} \mathrm{ha}^{-1} \mathrm{~N}$ (Table 3). It seems that when there is no stress, plant roots perform better in $\mathrm{N}$ uptake and as more $\mathrm{N}$ is absorbed, the chlorophyll content of green organs of the plants is increased (Mirzakhani \& Sajedi, 2015), but under water stress, the presence of $\mathrm{N}$ in the medium could not enhance chlorophyll content, which can be related to the decrease in $\mathrm{N}$ uptake, the decrease in leaf $\mathrm{N}$ content, and the disruption of chlorophyll synthesis process under water deficit conditions (Babaeian et al., 2010). (Saeedipour, 2012) reported a decrease in chlorophyll $a$ content with an increase in irrigation interval and its increase with $\mathrm{N}$ fertilization, which is consistent with our results. Less $\mathrm{N}$ uptake under stressful conditions, especially drought stress, and the accompanying loss of leaf $\mathrm{N}$ content can disrupt chlorophyll $a$ synthesis process because $\mathrm{N}$ is involved not only in protein structure but also in the structure of chlorophyll molecule. (Safaei et al., 2011) found that drought stress impaired chlorophyll synthesis by limiting the $\mathrm{N}$ uptake potential of the plant. When plants are exposed to drought stress, chlorophyll starts to break down its constituents, but they are re-synthesized due to the stress. (Khadem et al., 2010) concluded that maintaining chlorophyll content under stress conditions contributed to photosynthesis stability.

\subsection{Chlorophyll b content}

Chlorophyll $b$ content was influenced by the interaction of low irrigation and $\mathrm{N}$ fertilization at the $p<0.05$ level and by the interaction of low irrigation, $\mathrm{N}$ fertilization, and ecotype at the $p<$ 0.01 level, but the impact of different levels of low irrigation, $\mathrm{N}$, and ecotype was not significant on this trait (Table 2). Means comparison for the interaction of the studied three factors shows that the highest chlorophyll $b$ content of $0.36 \mathrm{mg} \mathrm{g}^{-1}$ was obtained from Bushehry ecotype irrigated to supply $75 \%$ of PWR and treated with $150 \mathrm{~kg} \mathrm{ha}^{-1} \mathrm{~N}$. No significant differences were observed among other treatments (Table 4). The lack of a significant difference among the treatments can be associated with the fact that under drought stress, the photosynthesizing systems of photosystem II are influenced to a less extent than that of the photosystem.

Table 4: Means comparison for interaction of low irrigation, $\mathrm{N}$ fertilization and ecotype for the studied traits

\begin{tabular}{|c|c|c|c|c|c|c|c|c|}
\hline $\begin{array}{c}\text { Drought } \\
\text { stress }\end{array}$ & $\begin{array}{c}\mathrm{N} \\
\text { rate }\end{array}$ & Ecotype & $\begin{array}{c}\text { Active } \\
\text { ingredient }\end{array}$ & $\begin{array}{c}\text { Chlorophyll } \\
a\end{array}$ & $\begin{array}{c}\text { Chlorophyll } \\
b\end{array}$ & $\begin{array}{c}\text { Total } \\
\text { chlorophyll }\end{array}$ & $\begin{array}{c}\text { Chlorophyll } \\
a / b\end{array}$ & $\begin{array}{c}\text { Chlorophyll } \\
\text { index }\end{array}$ \\
\hline $\begin{array}{c}100 \% \\
\text { of PWR }\end{array}$ & $\begin{array}{c}50 \\
\mathrm{~kg} \mathrm{ha}^{-} \\
1\end{array}$ & Bami & $12.86 \mathrm{~cd}$ & $0.43 \mathrm{ghi}$ & $0.13 \mathrm{~b}$ & $0.56 \mathrm{ef}$ & $3.50 \mathrm{~b} . . \mathrm{e}$ & $48.95 \mathrm{~d}$ \\
\hline & & Bushehri & $14.28 \mathrm{~cd}$ & $0.46 \mathrm{f} . \mathrm{i}$ & $0.12 \mathrm{~b}$ & $0.57 \mathrm{ef}$ & $3.86 \mathrm{a} . . \mathrm{e}$ & $54.80 \mathrm{~cd}$ \\
\hline & & Rudbari & $13.43 \mathrm{~cd}$ & $0.51 \mathrm{~d} . . \mathrm{i}$ & $0.20 \mathrm{~b}$ & $0.71 \mathrm{de}$ & $2.53 \mathrm{def}$ & $68.28 \mathrm{ab}$ \\
\hline
\end{tabular}




\begin{tabular}{|c|c|c|c|c|c|c|c|c|}
\hline & $\begin{array}{c}100 \\
\mathrm{~kg} \mathrm{ha}^{-}\end{array}$ & Bami & $14.52 \mathrm{c}$ & 0.64 a..e & $0.17 \mathrm{~b}$ & $0.81 \mathrm{bc}$ & 3.72 b..e & $67.87 \mathrm{ab}$ \\
\hline & & Bushehri & $13.48 \mathrm{~cd}$ & 0.63 a..e & $0.20 \mathrm{~b}$ & $0.83 \mathrm{bc}$ & 3.08 b.ff & $77.40 \mathrm{a}$ \\
\hline & & Rudbari & $14.25 \mathrm{~cd}$ & 0.66 a..d & $0.20 \mathrm{~b}$ & $0.86 \mathrm{bc}$ & 3.33 b..f & $64.30 \mathrm{bc}$ \\
\hline & $\begin{array}{c}150 \\
\mathrm{~kg} \mathrm{ha}^{-}\end{array}$ & Bami & $13.55 \mathrm{~cd}$ & $0.74 \mathrm{ab}$ & $0.21 \mathrm{~b}$ & $0.95 \mathrm{ab}$ & 3.48 b..e & $59.2 \mathrm{~b}$ \\
\hline & & Bushehri & $14.57 \mathrm{c}$ & $0.76 \mathrm{a}$ & $0.19 \mathrm{~b}$ & $0.96 \mathrm{ab}$ & 3.95 a..e & $66.88 \mathrm{~b}$ \\
\hline & & Rudbari & $13.18 \mathrm{~cd}$ & $0.74 \mathrm{ab}$ & $0.20 \mathrm{~b}$ & $0.95 \mathrm{ab}$ & 3.58 b..e & $66.47 \mathrm{~b}$ \\
\hline \multirow[t]{9}{*}{$\begin{array}{l}75 \% \text { of } \\
\text { PWR }\end{array}$} & $\begin{array}{c}50 \\
\mathrm{~kg} \mathrm{ha}_{1}^{-}\end{array}$ & Bami & $20.03 \mathrm{a}$ & 0.59 d..i & $0.18 \mathrm{~b}$ & 0.69 cde & 2.75 c..f & $38.70 \mathrm{e}$ \\
\hline & & Bushehri & $19.60 \mathrm{~b}$ & $0.40 \mathrm{hi}$ & $0.15 \mathrm{~b}$ & 0.55 ef & 2.78 c..f & 30.57 e..h \\
\hline & & Rudbari & $17.95 \mathrm{~b}$ & 0.44 ghi & $0.13 \mathrm{~b}$ & $0.57 \mathrm{ef}$ & 3.56 b..e & $31.52 \mathrm{efg}$ \\
\hline & $\begin{array}{c}100 \\
\mathrm{~kg} \mathrm{ha}_{1}^{-}\end{array}$ & Bami & $19.56 \mathrm{ab}$ & 0.61 a..f & $0.14 \mathrm{~b}$ & $0.75 \mathrm{cde}$ & 4.64 a..d & $26.56 \mathrm{f} . . \mathrm{i}$ \\
\hline & & Bushehri & $18.88 \mathrm{ab}$ & 0.65 a..d & $0.13 \mathrm{~b}$ & $0.80 \mathrm{bcd}$ & $5.07 \mathrm{ab}$ & $52.22 \mathrm{f} . . \mathrm{j}$ \\
\hline & & Rudbari & $18.22 \mathrm{~b}$ & 0.59 b..g & $0.16 \mathrm{~b}$ & $0.75 \mathrm{cde}$ & 3.78 b..e & 30.36 e..h \\
\hline & $\begin{array}{c}150 \\
\mathrm{~kg} \mathrm{ha}_{1}^{-}\end{array}$ & Bami & $20.61 \mathrm{a}$ & $0.72 a b c$ & $0.12 \mathrm{~b}$ & $0.84 \mathrm{bc}$ & $5.97 \mathrm{a}$ & 34.03 ef \\
\hline & & Bushehri & $19.19 \mathrm{ab}$ & $0.69 \mathrm{abc}$ & $0.36 \mathrm{a}$ & $1.05 \mathrm{a}$ & 3.66 b..e & 28.90 e..h \\
\hline & & Rudbari & $19.12 \mathrm{ab}$ & $0.70 a b c$ & $0.14 \mathrm{~b}$ & $0.85 b c$ & $4.99 a b c$ & 24.19 f..k \\
\hline \multirow[t]{9}{*}{$\begin{array}{c}50 \% \text { of } \\
\text { PWR }\end{array}$} & $\begin{array}{c}50 \\
\mathrm{~kg} \mathrm{ha}_{1}^{-}\end{array}$ & Bami & $13.51 \mathrm{~cd}$ & $0.26 \mathrm{~h}$ & $0.20 \mathrm{~b}$ & $0.46 \mathrm{f}$ & $1.27 \mathrm{f}$ & $26.04 \mathrm{fi}$ \\
\hline & & Bushehri & $12.81 \mathrm{~cd}$ & 0.48 e..i & $0.20 \mathrm{~b}$ & $0.68 \mathrm{cde}$ & 2.37 e..f & $25.31 \mathrm{f} . . \mathrm{j}$ \\
\hline & & Rudbari & $12.80 \mathrm{~cd}$ & $0.51 \mathrm{~d} . . \mathrm{i}$ & $0.18 \mathrm{~b}$ & 0.70 cde & 2.91 b..f & 21.08 g... \\
\hline & $\begin{array}{c}100 \\
\mathrm{~kg} \mathrm{ha}_{1}^{-}\end{array}$ & Bami & $13.50 \mathrm{~cd}$ & $0.46 \mathrm{f..i}$ & $0.13 \mathrm{~b}$ & $0.60 \mathrm{def}$ & 3.57 b..e & 20.65 h..k \\
\hline & & Bushehri & $13.41 \mathrm{~cd}$ & $0.51 \mathrm{~d} . . \mathrm{i}$ & $0.18 \mathrm{~b}$ & $0.70 \mathrm{cde}$ & 2.92 b..f & $17.25 \mathrm{ijk}$ \\
\hline & & Rudbari & $12.95 \mathrm{~cd}$ & $0.46 \mathrm{f} . . \mathrm{i}$ & $0.13 \mathrm{~b}$ & 0.59 def & 3.64 b..e & $15.01 \mathrm{jk}$ \\
\hline & $\begin{array}{c}150 \\
\mathrm{~kg} \mathrm{ha}_{1}^{-}\end{array}$ & Bami & $13.17 \mathrm{~cd}$ & $0.56 \mathrm{c} . \mathrm{h}$ & $0.14 \mathrm{~b}$ & $0.70 \mathrm{cde}$ & 4.11 a..e & $17.66 \mathrm{ijk}$ \\
\hline & & Bushehri & $12.55 \mathrm{~d}$ & 0.57 c..g & $0.12 \mathrm{~b}$ & $0.69 \mathrm{cde}$ & $4.87 \mathrm{abc}$ & $14.31 \mathrm{k}$ \\
\hline & & Rudbari & $13.23 \mathrm{~cd}$ & $0.40 \mathrm{i}$ & $0.20 \mathrm{~b}$ & $0.60 \mathrm{def}$ & 2.01 e.f & $14.51 \mathrm{k}$ \\
\hline
\end{tabular}

Means with similar letter(s) in each column were not significantly different.

\subsection{Total chlorophyll content}

This trait was influenced by different levels of low irrigation, $\mathrm{N}$ fertilization, and the interaction of these factors significantly at $p<0.05, p<0.01$, and $p<0.05$ levels, respectively (Table 2). Means comparison for the interaction of low irrigation and $\mathrm{N}$ fertilization (Figure 1) showed that the highest total chlorophyll was obtained from the plants that were irrigated to supply $100 \%$ or $75 \%$ of PWR and that were fertilized with $150 \mathrm{~kg} \mathrm{ha}^{-1} \mathrm{~N}\left(0.98\right.$ and $0.92 \mathrm{mg} \mathrm{g}^{-1}$, respectively). However, these two treatments did not differ significantly from the treatment of $100 \mathrm{~kg} \mathrm{ha}^{-1}$ and 
irrigation to supply the whole PWR. The increase in irrigation interval from $75 \%$ to $50 \%$ of PWR reduced leaf chlorophyll content significantly, and there were not any significant differences between various rates of $\mathrm{N}$ fertilization at this irrigation level. Also, irrigation to supply $100 \%$ and $75 \%$ of PWR accompanied by the application of $50 \mathrm{~kg} \mathrm{ha}^{-1} \mathrm{~N}$ resulted in the loss of chlorophyll. Chlorophyll content of the living plants is a critical factor to keep photosynthesis. Meanwhile, the effect of drought on chlorophyll $a$ and $b$ contents varies among the plants with the drought intensity, drought duration, and growth stage. Kirnak et al. (2001) reported that leaf chlorophyll content was reduced under drought stress. Our findings of the loss of chlorophyll content are consistent with (Abbaszadeh et al., 2008)'s study on maize and Sanchez-Blanco et al. (2006)'s study on rosemary. According to (Ding et al., 2005), these compounds have nitrogenous structure. Thus, the application of nitrogen can improve these traits to a great extent. These results are in agreement with the findings of (Sifola \& Barbieri, 2006) about basils, (Abbaszadeh et al., 2008) about balm, (Sarajuoghi et al., 2014) about Thymus vulgaris L., and (Razavi Nia et al., 2015) on Echinaceaepursuerea (L.) Moench.

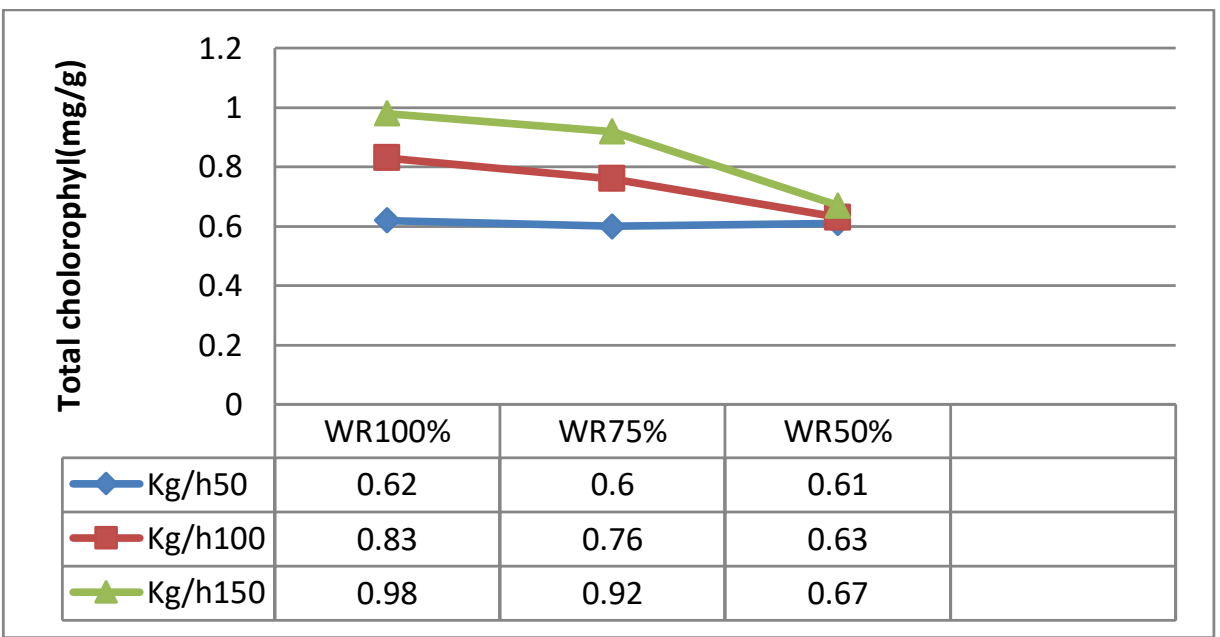

Figure 1: Means comparison for the interaction of low irrigation and $\mathrm{N}$ fertilization for total chlorophyll content of leaf

\subsection{Chlorophyll a/b ratio}

Chlorophyll $a / b$ ratio was influenced by different levels of low irrigation $(p<0.05), \mathrm{N}$ fertilization $(p<0.01)$, and interaction between low irrigation, $\mathrm{N}$ rate, and ecotype at the $p<0.01$ level (Table 2). Irrigation to supply 75\% of PWR of Bami and Bushehri that were fertilized with 150 and $100 \mathrm{~kg} \mathrm{ha}^{-1}$, respectively, resulted in the highest chlorophyll $a / b$ ratios of 5.97 and 5.07 $\mathrm{mg} \mathrm{g}^{-1}$. However, some other treatments showed increases in ratio, but they did not significantly differ in this trait from the superior treatments (Table 4). Also, the lowest ratio was obtained from Bami, Bushehri and Rudbari irrigated to supply 50\% of PWR and fertilized with 50, 50, and $150 \mathrm{~kg} \mathrm{ha}^{-1}$, respectively. Hong Bo et al. (2005) reported that the chlorophylla/b ratio changed in drought stress. The results of this study are in agreement with other studies (Siddique et al., 2000) and (Ludlow \& Muchow, 1990).

\subsection{Chlorophyll index}

According to the results of the analysis of variance, there were significant differences in 
chlorophyll index among different levels of water stress $(p<0.01)$ and among different $\mathrm{N}$ rates $(p<0.05)$. Although the effect of ecotype was not significant on this trait, the interaction of ecotype with low irrigation and the interaction of low irrigation, $\mathrm{N}$ fertilization, and ecotype were significant for this trait at the $p<0.01$ level (Table 2). According to the results, the highest chlorophyll index was obtained from ecotype Bushehri fertilized with $100 \mathrm{~kg} \mathrm{ha}^{-1} \mathrm{~N}$, Bami fertilized with $100 \mathrm{~kg} \mathrm{ha}^{-1} \mathrm{~N}$, and Rudbari fertilized with $50 \mathrm{~kg} \mathrm{ha}^{-1} \mathrm{~N}$, all at irrigation level to supply $100 \%$ of PWR on the loss of leaf. Reynolds et al. (2007) stated that leaf chlorophyll content or stability was related to transpiration efficiency and its higher value improved water use efficiency in drought conditions. Similarly found that leaf greenness duration or stability as an index of leaf chlorophyll is an indicator of leaf water status and deeper root system. Besides, this characteristic shows a stronger photosynthesis system for the synthesis of assimilates and water extraction from soil. (Sifola \& Barbieri, 2006) reported that drought stress accelerated leaf senescence by reducing leaf chlorophyll and dissolved proteins and that this decline happened earlier in more sensitive genotypes. Also, the impact of $\mathrm{N}$ on chlorophyll increase can be related to the involvement of $\mathrm{N}$ in chlorophyll structure (Azadbakht, 1999). Also, (Pandey \& Singh, 2010)found that the leaf chlorophyll ratio was higher in plants treated with a higher $\mathrm{N}$ rate, which is in agreement with our findings.

\subsection{Correlation coefficients of the traits}

The results for the correlation of the traits (Table 5) reveal that the highest positive and significant correlation was related to the coefficient of correlation of 0.92 for the correlation between the active ingredient and chlorophyll $a / b$ ratio $(p<0.01)$. The dye as the most important active ingredient of henna showed a high correlation with chlorophyll $b$, total chlorophyll, and chlorophyll index. The significance of coefficients of correlation, even for small coefficients, due to the high number of treatments and the resulting increase in degrees of freedom has been reported by (Reynolds et al., 2007). (Keshavarz et al., 2013) reported a positive significant correlation $\left(0.97^{* *}\right)$ between chlorophyll content and leaf $\mathrm{N}$ percentage. The negative significant correlation between chlorophyll $b$ and chlorophyll $a / b$ ratio and the positive significant correlation of chlorophyll $a$ and chlorophyll $b$ with total chlorophyll have been reported by (Hajizadeh et al., 2011).

Table 5: Coefficients of correlation between the measured traits

\begin{tabular}{|c|c|c|c|c|c|c|}
\hline & $\begin{array}{c}\text { Active } \\
\text { ingredient }\end{array}$ & Chlorophyll $a$ & Chlorophyll $b$ & $\begin{array}{c}\text { Chlorophyll } \\
a / b\end{array}$ & $\begin{array}{c}\text { Total } \\
\text { chlorophyll }\end{array}$ & $\begin{array}{c}\text { Chlorophyll } \\
\text { index }\end{array}$ \\
\hline $\begin{array}{c}\text { Active } \\
\text { ingredient }\end{array}$ & 1 & & & & & \\
\hline Chlorophyll $a$ & $-0.06^{\mathrm{ns}}$ & 1 & & & & \\
\hline Chlorophyll $b$ & $0.37^{*}$ & $-0.51^{* *}$ & 1 & & & \\
\hline $\begin{array}{c}\text { Chlorophyll } \\
a / b\end{array}$ & $0.92^{* *}$ & $0.50^{* *}$ & $-0.38^{*}$ & 1 & & \\
\hline $\begin{array}{c}\text { Total } \\
\text { chlorophyll }\end{array}$ & $0.30^{*}$ & $0.43^{* *}$ & $0.04^{\mathrm{ns}}$ & $0.32^{*}$ & 1 & \\
\hline $\begin{array}{l}\text { Chlorophyll } \\
\text { index }\end{array}$ & $0.47^{* *}$ & $0.47^{* *}$ & $0.32^{*}$ & $0.46^{* *}$ & $0.25^{*}$ & 1 \\
\hline
\end{tabular}

$\mathrm{ns}, *$, and $* *$ show non-significance and significance at the $p<0.05$ and $p<0.01$ levels, respectively. 


\section{CONCLUSION}

The results of the current study showed that the effect of drought stress at various levels was significant on all traits except chlorophyll $b$. The effect of $\mathrm{N}$ fertilization was also significant on all traits except chlorophyll $b$. There was no significant difference among the ecotypes. However, all traits except chlorophyll $a$ and total chlorophyll were influenced by the interaction of the three studied factors. The results lead us to the conclusion that the application of $100 \mathrm{~kg} \mathrm{ha}^{-1} \mathrm{~N}$ accompanied by stress at the rate of $75 \%$ of PWR can contribute to having more fresh plants with higher active ingredients.

\section{REFERENCES}

Abbaszadeh, B., Sharifi Ashourabadi, E., Lebaschi, M., Naderi Hajibagher Kandy, M., \& Moghadami, F. (2008). The effect of drought stress on proline contents, soluble sugars, chlorophyll and relative water contents of balm (Melissa officinalis L.), Iranian Journal of Medicinal and Aromatic Plants, 23(4), 504-513.

Altinkut, A., Kazan, K., \& Gozukirmizi, D. (2001), Tolerance to paraquat is correlated with the associated with water stress tolerance in segregation F2 populations of barley and wheat. Euphytica, 12(1), 81-86.

Azadbakht, M. (1999). Taxonomy of medicinal plant species (1st ed). Tehran: Nashr-e Tayyeb Publishing; 13(4), 125-136. (In Persian)

Babaeian, M., Heidari, M., \& Ghanbari, A. (2010). Effect of water stress and foliar micronutrient application on physiological characteristics and nutrient uptake in sunflower (Helianthus annus L.). Iranian Journal of Crop Sciences, 12(4), 377-391.

Chaudhary, G., Goyal, S., \& Poonia, P. (2010). Lawsoniainermis Linnaeus: A Phytopharmacological Review. International Journal of Pharmaceutical Sciences and Drug Research, 2(2), 91-98.

Ding, L., Wang, K., Jiang, D., Biswas, H., Xu, L., \& Li Y. (2005). Effects of nitrogen deficiency on photosynthetic traits of maize hybrids released in different years. Annal Bot, 9(6), 925-930.

Fredeen, A., Gamon, C., \& Field, B. (1991). Responses of photosynthesis and carbohydrate partitioning to limitations in nitrogen and water availability in field grown sunflower. Plant Cell Environ, 14(5), 963-970.

Hajizadeh, A., Maghsoudi Mud, G., Mohammadinejad, S., Tabatabaei, M., Mollaheidari, R., \& Zarandi, S. (2011). The effect of salinity on chlorophyll content in 20 sensitive and tolerant genotypes of bread wheat. Proceeding of 1 st National Conference on New Issues in Agriculture. Saveh, Iran: Islamic Azad University, 12(7), 369-380.

Ibrahimi, A. (2001). The need for systematic attitude towards the management of sustainable development of medicinal herbs. Proceeding of National Conference of Medicinal Herbs (p. 280). Research Institute of Forests and Rangelands, 4(3), 44-63. (In Persian)

Jones, H. (1980). Interaction and integration of adaptive responses to water stress: the implications of an unpredictable environment, New York: In Adaptation od plant to water and High Temperature stress (Ed.by N.C Turner \& P.J. Kramer), Wiley, 19(3), 353-365.

Keshavarz, L., Farahbakhsh, H., \& Golkar, P. (2013). Effect of hydrogel and irrigation regimes on chlorophyll content, nitrogen and some growth indices and yield of forage millet (Pennisetumglaucum L.). Journal of Crop Production and Processing, 3(9), 147-161.

Khadem, S., Galavi, M., Ramrodi, M., Mousavi, S., Rousta, M., \& Rezvani-moghadam, P. (2010). Effect of animal manure and superabsorbent polymer on corn leaf relative water content, cell membrane stability and leaf chlorophyll 
content under dry condition. Australian Journal of crop Science, 4(8), 642-647.

Ludlow, M., \& Muchow, R. (1990). A critical evolution of traits for improving crop yield in water-limited environmental. Adv Agron, 4(2), 107-153.

Mirzakhani, M., \& Sajedi, A. (2015). Evaluation of biological and chemical fertilizers on fertilizer use efficiency, grain yield and yield components of sunflower. Journal of Agricultural Science and Sustainable Production, 25(2), 139-153.

Molden, A. (2007). Water for food, water for life: A comprehensive assessment of water management in agriculture. London: Earthscan-Colombo: International Water Management Institute, 6(1), 59-71.

Orwa, C., Mutua, R., Kindt, R. \& Jamnadass, A. (2009). Agroforestree Database Lawsoniainermis (Henna). A tree reference and selection guide version, 14(6), 189-202.

Osareh, M., \& Akhlaghi, M. (2009). Development of research on natural resources of Iran. Research Institute of Forests and Rangelands, 9(2), 118-130. (In Persian)

Pandey, R., \& Singh, R. (2010). Genetic studies for biochemical and quantitative characters in grain amaranth (Amaranthushypochondriacus L.). Plant Omics Journal, 3(4), 129-134.

Pandya, G., Prajapata, M., \& Vashi, S. (1996). Estimates of genetic variability parameters in safflower. Gujarat Agric Univ Res J, 2(1), 13-16.

Petropoulos, S., Dimitra, D., Polissiou, M., \& Passam, H. (2008). The effect of water deficit stress in the growth, yield and composition of essential oils of parsley and peppermint. ScientiaHorticulturae, 11(5), 393-405.

Rajala, A., Hakala, P., Makela, S., Muurinen, F., \& Peltonen-Sainio, P. (2009). Spring wheat response to timing of water deficit through sink and grain filling capacity. Field Crops Res, 11(4), 263-271.

Razavi Nia, S., Aghaalikhani, M., \& NaghdiBadi, H. (2015). Effect of vermicompost and chemical fertilizers on quantitative and qualitative properties of Echinaceaepursuerea (L.) Moench. Iranian Journal of Medicinal and Aromatic Plants, 31(2), 357-373.

Reynolds, M., Saint Pierre, A., Saad, M., Vargas, A., \& Condon D. (2007). Evaluating potential genetic gains in wheat associated with stress-adaptive traits expression in elite genetic resources under drought and heat stress. Crop Science, 47(3), 172-189.

Roleda, M., Lutz-Meindl, U., Wiencke, C., \& Lutz, C. (2010). Physiological biological and ultrastructural responses of the green macroalga Urosporapencilliformis from Artic Spitsbergen to UV radation protoplasma, 24(3), 105-116.

Saeedipour, S. (2012). Appraisal of some physiological traits in two wheat cultivars subjected to terminal drought stress during grain filling. African Journal of Biotechnology, 11(83), 14884-14888.

Safaei, L., Zeinali, H., \& Afiuni, D. (2011). Study of genetic variation of agronomic characteristics in Foeniculumvulgare Mill, Genotypes. Iranian Journal of Rangelands and Forests Plant Breeding and Genetic Research, 19(1), 167-180.

Sarajuoghi, M., Abbaszadeh, B., \& Ardakani, M. (2014). Investigation morphological and physiological response of Thymus vulgaris L, to drought stress. Journal of Biodiversity and Environmental Sciences, 5(2), 486-492.

Siddique, M., Hamid, M., \& Islam S. (2000). Drought stress effects on water relations of wheat. Bot Bull Acad Sin, $4(1), 35-39$.

Sifola, M., \& Barbieri, G. (2006). Growth, yield and essential oil content of three cultivars of basil grown under different levels of nitrogen in the field. Scientia Horticulturae, 10(8), 408-413. 
Taherkhani, T., \& Rahmani, N., Moradi, A., \& Zandi, P. (2011). Assessment of nitrogen levels on flower yield of Calendula grown under different water deficit stress using drought-tolerant indices. Journal of American Science, 7(10), 591-598.

Valadabadi, S., Aliabadi Farahani, H., \& Moaveni, P. (2010). Investigate effect of nitrogen application on essential oil content and seed yield in different cumin (Cuminumcyminum L.) populations at Qazvin zone. Iranian Journal of Medicinal and Aromatic Plants, 26(3), 348-357.

Vazque, Z. (2010). Essential oil content and composition of Silybummarianum at different irrigation regimes. Journal of Agronomy, 10(2), 969-1002. 